\title{
HEZBOLLAH, THE ISLAMIC ASSOCIATION AND LEBANON'S CONFESSIONAL SYSTEM
}

Al-Infitah and Lebanonization

Robert G. Rabil*

\begin{abstract}
This essay examines two Lebanese Islamist parties, Hezbollah and the Islamic Association, putting under scrutiny both their ideological transformations and the particular circumstances attendant to their later participation in Lebanon's confessional political system. The article explores the ideological and political motives behind these parties' infitah (opening up) and lebanonization orientations, as expressed in their religious-political ideologies, political programs, and policies and visions in relation to Lebanon's confessional system. At the same time, this study probes the plausibility of the claim that Hezbollah's relatively recent integration into the state may have been a venue for it to shed its Jihadi character and transition into a conventional political party.
\end{abstract}

\section{The Internal and Regional Setting: Toward Taif and Syrian Hegemony}

Lebanon as an independent state was founded in 1943 on the basis of the National Pact; an entente between Christian and Muslim political elites then representative of the seventeen ethnoreligious communities that constituted the modern Lebanese Republic. This compact was institutionalized into a confessional structure of power-sharing, allocating political office along religious lines, and officiating political sectarianism or sectarian representation and distribution of institutional power within the system. Based on this accord, the Christian Maronites obtained imtiyazat (political privileges/prerogatives) that helped consecrate the systemic assertiveness of their political leadership. The civil war, which erupted in 1975, gradually but steadily gnawed at this political Maronitism. ${ }^{1}$ Significantly, the fortunes of the Maronites sank to a new low in 1988 when President Amin Gemayel's term neared its end. The president, torn between domestic, regional and international pressures, was unable to present the Lebanese parliament with an agreed-upon list of presidential hopefuls, as mandated by the constitution. Thus, before leaving office, he appointed General Michel Aoun to head an interim executive cabinet until a president was agreed upon and elected. ${ }^{2}$ Pro-Syrian deputies disapproved of Aoun's appointment, regarding it constitutionally illegitimate, and lent their support to the government of then Prime Minister Salim al-Hoss. At that time, Lebanon witnessed two authorities: one de jure, led by Aoun and exercising its authority over the Christian-dominated areas of the country, the other de

\footnotetext{
${ }^{1}$ Pan-Arabists and Leftists, including the Druze leader Kamal Junblat, were among the first to use interchangeably the terms Political Maronitism and the Maronite Regime to describe Maronite hegemony over the state.

${ }^{2}$ The United States, Israel, Syria and Lebanese Christians and Muslims all preferred different candidates. Frustrated, President Gemayel appointed General Aoun. I sat in on a meeting with President Gemayel, Archbishop Elia Elia of the Catholic Orthodox Church, and Maronite Chairbishop Joseph Lahoud at the Sheraton Commander in Cambridge, MA in September 1991, during which the question over Aoun's appointment was discussed.
} 
facto and pro-Damascus, led by Hoss and extending its authority over the areas under Syrian control.

In March 1989, General Aoun proclaimed a "liberation war" against Syria. His war was to take the form of an intifada against Syrian domination similar to that of the Palestinians in the West Bank. ${ }^{3}$ Syria responded by shelling the Christian area under Aoun's control and imposing on it a sea-and-land blockade - especially on East Beirut. In view of the constitutional impasse and the escalation of hostilities that ensued, and at the urging of Saudi Arabia, Lebanese deputies left for the resort-town of Taif in the Arabian Peninsula. At a meeting convened there, and with the intercession of Arab delegates from Algeria, Morocco, and Saudi Arabia, the Lebanese deputies managed to introduce significant amendments to the Lebanese constitution. The new version of the constitution became known interchangeably as the Document of National Understanding and the Taif Accord. General Aoun opposed the Taif Accord as a Syrian scheme to whittle away at Maronite power. In addition, over Aoun's objections, the deputies elected Elias Hrawi president. Aoun impugned the legitimacy of the proceedings and refused to recognize the new president. On August 21, 1990, the Lebanese parliament approved the constitutional amendments introduced by the Taif agreement, which were subsequently signed into law by President Hrawi on September 21.

It was against this background that Iraq rocked the region by invading Kuwait in early August 1990. The United States needed Syria's help in forming the international and Arab anti-Iraq coalition to extract Iraq from Kuwait. On October 13, the Syrian army, along with a unit of the Lebanese army under the Command of Colonel Emile Lahoud, launched an all-out attack on Aoun's forces. The Syrian air force intervened for the first time in the history of the Lebanese conflict and bombed Aoun out of the Presidential Palace. Within hours, East Beirut, the last bastion of Lebanese opposition to Syria, fell. Obviously, the United States had yielded to Assad's demand for total hegemony over Lebanon as a price for bringing Syria into the U.S.-led anti-Iraq coalition. No less significant, a by-product of the Gulf War, was the launching of the Madrid Peace Conference, with Syrian participation.

The collapse of East Beirut and the emergence of a "new Lebanon," the Second Republic, under Syrian hegemony, expedited the implementation of the Taif Accord. ${ }^{4}$ The Accord was divided into three parts: General Principles and Reforms (political and other reforms); Extending Lebanese Sovereignty over All Lebanese Territories; and Liberating Lebanon from Israeli Occupation.

The Document stated that Lebanon was a free, sovereign state, and a definitive homeland to all its citizens; it further specified that Lebanon was now Arab in identity and affiliation. The thrust of political reforms as mandated by the Taif Accord revolved around conferring equal powers to the three highest posts in the land. Executive power was transferred from the President to the Council of Ministers, which would set the general policy of the state, supervise the activities of

\footnotetext{
${ }^{3}$ Karim Pakradouni, La'nat Watan: Min Harb Lubnan Ila Harb al-Khalij (Curse of a Fatherland: From the Lebanese War to the Gulf War) (Beirut: Trans-Orient Press, 1992), p. 205.

${ }^{4}$ For the text of the Taif Accord see an-Nahar, August 22, 1990; For an analysis of the Accord, see Fida Nasrallah, Prospects for Lebanon: The Question of South Lebanon (Oxford: Centre for Lebanese Studies, 1992); and Joseph Maila, The Document of National Understanding: A Commentary (Oxford: Centre for Lebanese Studies, 1992).
} 
all state agencies, draft bills and decrees, and take the necessary measures for their implementation. The President would name a Prime Minister on the basis of consultations with the Speaker of the Chamber (Parliament). He could attend a meeting of the Council of Ministers, but without the right to vote.

The Chamber was enlarged to 108 members, divided equally between Muslims and Christians and apportioned according to sectarian affiliation. The Chamber, being the legislative authority, would exercise full control over government policies and activities. The Speaker's term was increased to four years. The electoral law would be based on the province (governorate) in light of cross-sectarian representation. Political sectarianism would be abolished in phases, set by a national committee. But, in the meantime, all posts in the civil service with the exception of the top three, would be accorded on the basis of competence. Other reforms included administrative decentralization.

With regard to Lebanese-Syrian relations, the Accord underscored that "Lebanon, which is Arab in identity and affiliation, is bound by fraternal, sincere relations to all Arab states and has special relations with Syria that draw their strength from the roots of kinship, history and common internal interests."

Admittedly, the Taif Accord did introduced major reforms into Lebanon's political system; yet confessional representation continued to be the dominant principle of government, as the new distribution of power remained an expression of a confessional formula. Augustus Richard Norton remarked that "[d]econfessionalization is stated as an explicit goal in the agreement, but without a specified deadline or timetable. The accord effectively concedes the futility of any serious attempt to expunge political sectarianism in Lebanon, at least for the foreseeable future [...] The accord leaves no doubt that, rhetoric aside, confessionalism is here to stay for some time to come."

But this view had an opposite side within the Christian community. In fact, Christians had mixed feelings about the Taif Accord. The very "confessionalism" that had up until then protected their prerogatives, has now given way to a "confessionalism" that was robbing them of their privileges. Some Christians saw in the Taif Accord a denouement of the constant attempts to abolish political Maronitism; they had already seen the writing on the wall and were girding themselves for these imminent changes in the new confessional equation of power. Others rejected the Taif outright and refused to acknowledge the sea change overtaking Lebanon. All of these feelings played themselves out in a community frayed at the seams by internecine squabbling and fighting. ${ }^{7}$

Meanwhile, in line with the Taif Accord's emphasis on the Lebanese-Syrian "special relations," the Syrian and Lebanese presidents signed the May 20, 1991 Treaty of Brotherhood Cooperation and Coordination, and the September 1, 1991 Lebanon-Syria Defense and Security Agreement,

\footnotetext{
${ }_{6}^{5}$ Ibid.

${ }^{6}$ Augustus Richard Norton, "Lebanon After Ta'if: Is the Civil War Over?" Middle East Journal, Vol. 45, No. 3 (Summer 1991), p. 461.

${ }^{7}$ Author had discussions with members of the Lebanese Forces, Phalangists, and Aoun supporters throughout 1991 and 1992.
} 
which institutionalized Syrian trusteeship (occupation) over Lebanon. ${ }^{8}$ Before long, with Syrian prodding, parliamentary elections were scheduled for summer 1992, after a hiatus of two decades.

\section{Hezbollah and the Political System: Infitah (opening up) and Lebanonization?}

Founded officially in 1985 as an Islamist, Jihadist movement, the Shia Party of God or Hezbollah was concerned with domestic and regional developments. The party's agenda, as expressed in its first Manifesto, 'The Open Letter', which was issued in February 1985, revolved around abolishing the Maronite regime (political Maronitism) and establishing an Islamic state in Lebanon. ${ }^{9}$ It also sought to prosecute the political elites of the Maronite regime who collaborated with Israel. However, since Hezbollah had not yet political representation and thus no say in the outcome of the Taif Accord, and in light of the regional changes spurred by Iraq's invasion of Kuwait, the Islamist party was extremely wary and concerned about both the upcoming Lebanese elections and the changes they might bring about, and the ramifications of the Taif Accord's implementation on its Jihadi organization. The Islamist party initially opposed the Taif Accord because it did not lend itself to radical changes in line with Hezbollah's aspirations, and because it kept key governmental positions in the hands of the Maronites; namely the presidency of the republic and the army command had remained Maronite prerogatives. Additionally, Hezbollah's opposition to Taif stemmed in no small part from the Accord's dubious position with regards to Israel's occupation of South Lebanon. ${ }^{10}$

Hezbollah tried to create a political bloc opposing the Taif, but to no avail. Most political forces in Beirut supported the Taif Accord and were toeing the Syrian line. However, Hezbollah made a distinction between its political and military opposition, and opted not to stand in the way of the Taif's implementation. This calculated pragmatic decision was the outcome of several meetings between the party leadership and President Assad on one side, and the Lebanese government on the other. In dealing with the Taif, and by extension the sponsor of the accord Syria, Hezbollah based its decision making process on what it called al-Thawabit (immutable fundamentals/principles) and Maslaha (interest). Foremost among the Thawabit was the absolute enmity to Israel, while Maslaha was an expression of common denominators with other parties under the "ceiling" of Thawabit. The party leadership saw that Damascus was the only Arab capital confronting Israel, even after it had joined the Madrid Peace Conference. And it saw that the two (Damascus and Hezbollah) had a common interest in forcing Israel from Lebanon. ${ }^{11}$ Simultaneously, the Lebanese Defense and Agriculture Ministers (Muhsin Daloul and Albert Mansour) held a series of meetings with the party leadership in which they decided to create coordination committees to avert frictions and preempt future problems. Most importantly, Hezbollah's decision not to confront the government of the Second Republic, laid in the

\footnotetext{
${ }^{8}$ Rabil, Embattled Neighbors, pp. 130-132.

${ }^{9}$ For the Arabic text of the Open Letter see Hassan Fadlallah, Al-Khiyar al-Akhar: Hezbollah: Al-Sirah al-Zatiyyah wa al-Mawqaf (The Other Choice: Hezbollah's Autobiography and Stance) (Beirut: Dar alHadi, 1994), pp. 184-213; For an English translation of the text of the Open Letter, see Joseph Alagha, Hizbullah's Documents: From the 1985 Open Letter to the 2009 Manifesto (Amsterdam: Pallas Publications, 2011), pp. 39-55.

${ }^{10}$ Fadlallah, Al-Khiyar al-Akhar, pp. 109-110.

${ }^{11}$ Ibid., pp. 142-143.
} 
understandings with President Assad and the Lebanese government that the party's freedom of action would not be restricted, and its resistance against Israel would not be obstructed. ${ }^{12}$ Nevertheless, according to Hassan Fadlallah, it was the vision of President Assad that governed the development of Hezbollah-Syrian relations, as he was careful to nurture the resistance against Israel. $^{13}$

But if dealing with the Taif reflected some kind of a qualitative jump from rejectionism and radicalism to some sort of accommodation, it was the decision over whether to participate in the political system and the upcoming elections that would test the political flexibility and maturity of Hezbollah. Participation in the elections was essentially an admission of the legitimacy of the Lebanese political system, which the party had been adamant about abolishing. This decision entailed a scrutiny and an evaluation of the party's religious-political ideology, as expressed in the Open Letter conveying its evolution from a radical armed group into a vigorous social movement. Similarly, this decision to integrate the Lebanese political system also prefigured a definition of a political vision expressed in a coherent political program. This provoked an extensive internal debate within the party.

Deputy Secretary General of Hezbollah Naim Qassem gave a detailed account on the debate among Hezbollah's leading cadres regarding the party's participation in the Lebanese political system and parliamentary elections. Hezbollah's seven-member Shura (Consultative) Council and five leading members of the party formed a committee to assess the situation. Four questions were at the heart of the debate: 1) the legitimacy of parliamentary participation in a confessional political system that does not represent Hezbollah's view of an ideal system, 2) were the legitimacy issue solved, would participation imply a recognition of the political system's reality, whereby the party would adopt and defend the system, foregoing its own Islamic vision, 3) are there disadvantages or benefits, which outweigh sure and clear benefits? and, 4) would participation lead to a re-adjustment of the party's priorities, whereby resistance would be abandoned in favor of partaking of the internal political game? ${ }^{14}$

Qassem explained that the committee could not address the question of legitimacy since it was the prerogative of the Just Jurisconsult (Wali al-Faqih), Ayatollah Ali Khamenei, Iran's supreme leader. So the committee comprehensively addressed the remaining questions in order to submit all standpoints to the Jurisconsult, who would ultimately define the doctrinal legitimacy regarding dealing with the regime and especially with the parliamentary elections.

The committee perceived that although participation in parliamentary elections is an expression of taking part in the political structure of the system, it does not accord a commitment to preserve the system. More so, participation has significant advantages, namely: 1) using the parliament as a political podium to take care of the Resistance and its matters; 2) drafting legislation to benefit the livelihood of people and oppressed areas; 3) taking a priori knowledge of legislations under discussion so as to study them and, if needed, to suggest amendments to them, thereby obviating the surprise of being bound by legislative realities that cannot be discussed after their official

\footnotetext{
${ }^{12}$ Ibid., p. 116.

${ }^{13}$ Ibid., p. 148; see also Naim Qassem, Hizbullah: Al-Manhaj, al-Tajribah, al-Mustaqbal (Hizbullah: The Curriculum [program], the Experience, The Future) (Beirut: Dar al-Hadi, 6th edition, 2009), pp. 152-154.

${ }^{14}$ Qassem, Al-Manhaj, al-Tajribah, al-Mustaqbal, pp. 333-334.
} 
adoption; 4) creating a network of political relationships with representatives of Lebanon's various sects and areas to conduct direct discussions, thereby removing false barriers and misperceptions; 5) granting Hezbollah official recognition from the Lebanese parliament, thereby conferring on the Resistance official and popular legitimacy, and finally 6) presenting an Islamic viewpoint on a variety of issues.

The committee also pointed out disadvantages to parliamentary representation, chief among them: 1) the difficulty of having a precise popular representation on account of the system's confessional allocation of the number of representatives, which renders representation in the parliament more political than numerical; 2) the enactment of laws contradictory to Shari'a (Islamic law), despite their opposition by Hezbollah's deputies; and 3) holding deputies responsible for delivering services to their constituencies, though his or her responsibility is to legislate while the cabinet has the power of execution.

Significantly, the committee underscored the fact that priorities are set by the party's political decision-making apparatus, which gave resistance against Israel's occupation precedence over all other priorities. Given that there are no preconditions linking parliamentary participation with the specificity of the "Resistance," and given that the party linked its participation in the elections to an explicit declaration about maintaining the priority of "resistance," the committee saw that there is no need for concern that such participation would have a negative bearing on resistance activity. Instead, elections constitute an additional capital supporting the Resistance.

Based on the above deliberations, the committee voted (ten out of twelve) in favor of parliamentary participation, not only as an interest but also as a necessity. ${ }^{15}$ This was harmonious with Hezbollah's total vision for defending the affairs and interests of people in the political realm, and not in conflict with the priority of Jihad for liberation. This also provided a new experience for a nascent Islamic party. Subsequently, the committee presented its findings to Ayatollah Khamenei and requested from him a legal opinion (Istifta') on the legitimacy of participating in the elections, which he authorized and supported (ajaza wa Ayyada). ${ }^{16}$ Immediately thereafter, the party began drafting its political program, and on July 3, 1992 announced its participation in Lebanon's parliamentary elections. This marked the Infitah (opening up) of Hezbollah to Lebanon's political system.

But this Infitah was not only made possible by the blessing of Ayatollah Khamenei. Ayatollah Muhammad Hussein Fadlallah played a crucial role in nudging the Islamist party towards what he termed Lebanonization of the Islamist movement in Lebanon, a term that became synonymous with Infitah. In fact, the Infitah can be traced to the second conclave of Hezbollah (May-July 1991) in which Sayyid Abbas al-Mussawi was elected Secretary General of the party and a working plan was fashioned to initiate dialogue with the Christians, excluding those Maronites who had ties with Israel and still represented the symbols of political Maronitism (Maronite regime). ${ }^{17}$ The path to fashioning the dialogue plan was paved by none other than Ayatollah Fadlallah, who removed the ideological and political obstacles between the Islamists and Christians. Ayatollah Fadlallah made non-sectarian common causes the focal point of the

\footnotetext{
${ }^{15}$ Ibid., pp. 335-338.

${ }^{16}$ Ibid., pp. 338-339.

${ }^{17}$ Fadlallah, Al-Khiyar al-Akhar, p. 137.
} 
Christian-Muslim dialogue. He believed that the attitude of the Muslims towards the People of the Book (Christians and Jews) stems from neither military considerations, nor from charged complex feelings. Therefore, claimed Fadlallah, there are prospects for Christian-Muslim coexistence, cooperation and dialogue, without making a concession of a strategic Islamic position or moving away from the reality of the total strategy of the Islamist movement. ${ }^{18}$ Ayatollah Fadlallah acted on his beliefs by engaging in an open dialogue with Christian intellectuals, politicians and clerics.

It follows from this that Ayatollah Fadlallah supported Hezbollah's engagement of Lebanon's political system as a means for the Islamist movement to electorally legitimize itself and to realize transitional goals without even confirming the legitimacy of the system. Such "Lebanonization" he explained, had to heed the unique circumstances of confessional Lebanon and the particular condition of the Maronites. Elucidating the concept and practice of Lebanonization, Ayatollah Fadlallah stated:

When I spoke of the Lebanonization of the Islamist movement in Lebanon, what I meant was that the Islamist movement should examine the prevailing circumstances in Lebanon and formulate its strategy within that framework, making allowances for Lebanon's particular circumstances, its confessional sensitivities, its perception of its environment. In other words, in spreading the faith, the Muslims in Lebanon should not follow procedures that would be inappropriate to Lebanon ... Examining the state of affairs in Lebanon, one finds that the Christian situation is more complicated than it is in other Arab or Islamic countries. Christians in Lebanon have a "complex, " or fear of the Islamic reality that leads them to seek control over the presidency of the republic and other key positions and things of that sort. So the Maronite question in Lebanon assumes a large dimension at the political, security, and cultural levels. The Islamists in Lebanon must be sensitive to the problem, taking care not to let it become a bone of contention that could lead to warfare among Lebanese, which would bring Islamic activities to naught, and Christian ones as well . . . Lebanon cannot be transformed into an Islamic republic, which is unrealistic, but the Islamists should give free reign to their ideas in Lebanon, taking advantage of the fact that Lebanon is not only a window on the West, but also a window for the West on the East. ${ }^{19}$

Over whether or not Hezbollah should participate in the parliamentary elections, Ayatollah Fadlallah explained:

Hizballah should enter the electoral arena if only for the sake of Islamic legitimacy in Lebanon, which dictates the formation of a parliamentary party. This is not to say that the Islamists have embraced the parliamentary system, but parliament does provide a forum where they can express their views and urge others, if not to adopt those views, at least to be more accommodating toward them. Participation in this system may enable Hizballah to realize some transitional goals. I believe that Hizballah has reached a stage

\footnotetext{
${ }^{18}$ Ibid., 138.

${ }^{19}$ Shaykh Muhammad Hussayn Fadlallah and Mahmoud Soueid, "Islamic Unity and Political Change: Interview with Shaykh Muhammad Hussayn Fadlallah," Journal of Palestine Studies, Vol. 25, No. 1 (Autumn, 1995), pp. 67-68.
} 
of reasonable political maturity. It has amassed expertise in military, security, cultural, and political affairs, which greatly enhances its chances of spreading its influence in Lebanon, despite the challenge from the international American-Israeli campaign against it. It would be very difficult to terminate the role of Hizballah, because that role has strong grass-roots support and is furthermore well grounded in its structure, methodology, thought, and political activities. ${ }^{20}$

Concomitantly, Ayatollah Fadlallah's support for Hezbollah's Lebanonization and participation in parliamentary elections helped undermine the position of the militants in the party and their supporters in Tehran, whose grip on power had begun to slip following the death of Ayatollah Khomeini and the election of Hashimi Rafsanjani as president. A. Nizar Hamzeh perceptively remarked that "Fadlallah's Lebanonization of Hizbullah has greatly undermined the position of extremists in the party." ${ }^{21}$ But, at the same time, it would be implausible to endorse Hamzeh's statement that "the shift in Hizbullah's orientation was tied largely to shifts within Iran's leadership." 22 Deputy Secretary General of Hezbollah Naim Qassem made it clear, as we have seen, that the shift was largely the result of an internal debate in the party in response to domestic and regional changes. But that does not mean that factional politics among Iran's leaders did not have a bearing on Hezbollah's decision-making process, as Amal Saad-Ghorayeb observed. ${ }^{23}$

Though Hezbollah's Lebanonization was inspired by Ayatollah Fadlallah, it employed a nuanced political discourse to describe Lebanonization and Infitah, whereby the two terms became synonymous without losing their literalist meanings. Speaking about Lebanonization, Secretary General of Hezbollah Hassan Nasrallah addressed the issue quite differently. He described Lebanonization in terms of patriotism. He questioned: What is non-Lebanese about Hezbollah, and needs to become Lebanese? He ascribed the highest level of patriotism to Hezbollah because it shed much blood liberating the Fatherland. Then he spoke about Lebanonization from the perspective that the Lebanese, by sharing common feelings and values, are able to form a single, cohesive community in the face of aggression. Because of this, Hezbollah will be more open and encouraged to forge stronger relations with other groups, and to be more forthcoming in interacting with various sectors of the Lebanese population. ${ }^{24}$

Interestingly enough, Lebanonization as a term and concept has taken a political dimension far from its original meaning, leading to a confused reading of Hezbollah's intentions and policies. Hezbollah's entry into Lebanon's political arena has raised questions about the future of the Islamist party. Some scholars, such as Augustus Richard Norton, Hala Jaber, Judith Palmer Harik, A. Nizar Hamzeh and Magnus Ranstorp, have argued in slightly different versions that Hezbollah's Lebanonization process would in due time transform the Islamist party into a conventional political party, shedding both its Jihadi character (especially vis-à-vis its struggle

\footnotetext{
${ }^{20}$ Ibid., p. 69.

${ }^{21}$ A. Nizar Hamzeh, "Lebanon's Hizbullah: From Islamic Revolution to Parliamentary Accommodation," Third World Quarterly, Vol. 14, No. 2 (1993), p. 324.

${ }^{22}$ Ibid., p. 323.

${ }^{23}$ Amal Saad-Ghorayeb, Hizbu'llah: Politics and Religion (London: Pluto press, 2002), p. 47.

${ }^{24}$ See Nasrallah interview with as-Safir, as transcribed in Nicolas Noe, ed., Voice of Hezbollah: The Statements of Sayyed Hassan Nasrallah (London: Verso, 2007), pp. 159-161.
} 
with Israel) and its long term ideal of an Islamic regime and state. ${ }^{25}$ This line of reasoning has become a sort of biblical mantra following Israel's withdrawal from south Lebanon in the summer of 2000, in spite of the fact that it was refuted by the party itself. Brushing aside the notion of making political concessions in return for political and administrative positions, Qassem sarcastically observed that "the repeated talks about the Lebanonization of Hezbollah and its admission into the internal political life is but another title of the necessity to abandon its fundamentals and the priority of resistance, and to stop fighting Israel and surrender its weapons and the reasons for its power." 26

Essentially, Lebanonization of Hezbollah is at the heart of the political process to support Hezbollah's Jihad and Resistance. In fact, this process did not begin until the party was sure about its socio-political and military power in the Lebanese milieu and was no longer concerned about the cost of politicization of Hezbollah at the expense of its resistance role. As Qassem asserted: "The introduction [identity] of Hezbollah, which has been fashioned in a way so as to interrupt the debate and resolve the relationship between the [party's] Jihadi and political aspects, is that 'the movement of Hezbollah is a Jihadi movement whose primary objective is the struggle [Jihad] against the Zionist enemy,' and 'the clever and sagacious political Jihad can and should be the buttress and pillar of this Jihadi movement'."27

This inseparable "organic" link between Hezbollah's political and Jihadi organizations was apparently ignored by the various aforementioned scholars of the Islamist party. Arguably, this oversight rested with the desire of the scholars to project an image of Hezbollah consistent with its pragmatic transformation into a political party far from its common "terrorist" stigma. But in so doing, they obfuscated and/or misread the true reality of Hezbollah, as a Jihadi movement commandeering political Jihad, to use Qassem's terminology. Interestingly, Mona Harb and Reinoud Leenders perceptively pointed out that "partly as a result of the shortcomings of the "terrorism" label, various analysts of Hizbullah developed a counter-view emphasizing the organization's gradual but unavoidable transformation into a conventional party that will be fully accommodated by the Lebanese political system." ${ }^{28}$ In emphasizing the failure of this

\footnotetext{
${ }^{25}$ Richard Augustus Norton, "Hizbullah: From Radicalization to Pragmatism?" Middle East Policy, Vol. 4, No. 4 (January 1998); Magnus Ranstorp, "The Strategy and Tactics of Hizballa's Current Lebanonization Process," Mediterranean Politics, Vol. 3, No. 1 (1998); Judith Palmer Harik, Hezbollah: The Changing Face of Terrorism (London: I.B. Tauris, 2004), pp. 51-52 and 73-78; Hala Jaber, Hezbollah: Born with a Vengeance (New York: Columbia University Press, 1997), pp. 205-214; and A. Nizar Hamzeh, "Lebanon's Hizbullah: From Islamic Revolution to Parliamentary Accommodation," Third World Quarterly, Vol. 14, No. 2 (1993). Most recently, Marlin Dick, writing in Middle East Report Online, emphasized that Hezbollah behaves more and more like a Chicago political machine than a branch of the Revolutionary Guards. Marlin Dick, "Hizballah's Domestic Growing Pains," Middle East Report Online, September 13, 2010; available at http://www.merip.org/mero/mero091310.html.

${ }^{26}$ Qassem, Al-Manhaj, al-Tajribah, al-Mustaqbal, p. 352.

${ }^{27}$ Ibid., p. 113.

${ }^{28}$ Mona Harb and Reinoud Leenders, "Know Thy Enemy: Hizbullah, 'Terrorism' and the Politics of Perception," Third World Quarterly, Vol. 26, No. 1 (2005), p. 192. It's noteworthy that Joseph Alagha has not refuted the link between the social and military organizations of Hezbollah. He argues that Hezbollah's practical engagement of Lebanon's political system, or Lebanonization, follows the party's political programs, and not the party's religious-political ideology. In his forthcoming work Hizbullah's Identity Construction, 1978-2010, he acknowledges Hezbollah's manipulation of the system. Joseph
} 
Lebanonization thesis to acknowledge the interactions between the armed and the civilian activities of Hezbollah, they proffered the thesis that Hezbollah's social and political activities operate as an integrated and holistic network, disseminating the values of resistance that produce what has been designated by the party as the Mujtama' al-Muqawamah (Resistance Society). ${ }^{29}$ The holistic network together with the "Resistance Society" it produces form the Hala alIslamiyah (Islamic religious-political sphere). Adhering to this Hala al-Islamiyah, in turn, "produces a collective identity generating a strong sense of belonging, which gives meaning to the individual." ${ }^{30}$ While Harb and Leenders aptly pointed out to Hezbollah's construction of the Resistance society, they failed to recognize that this Resistance society is not only limited to the Shia community in general and to the Hala al-Islamiyah in particular. In fact, Hezbollah has been keen on transforming (or integrating) Lebanese society into a Resistance society as part of its Islamist Resistance project, whereby the society at large would be integrated into the Resistance. In expounding the way in which the rest of society should integrate with the Resistance, Qassem asserted that:

Resistance for us is a societal vision in all its dimensions, for it is a military, cultural, political and informational [media] resistance. It is the resistance of the people and the mujahidin, it is the resistance of the ruler and the Ummah, it is the resistance of the free consciousness anywhere. As such, we have always called for building the society of resistance. Not one day have we accepted a group of resistance, because the society of resistance bears continuity, whereas the performance of the group of resistance is circumstantial. $^{31}$

\section{The Islamic Association and Lebanonization}

Former Secretary General of the Islamic Association Fathi Yakan had already ideologically paved the path for the participation of his party in Lebanon's confessional system. Yakan justified Islamic activism in Lebanon on the grounds of saving Muslims. He made the distinction between participation of Muslims and participation of Islam in the system. He explained that participation did not mean Islam participating in the rule of temporal regimes, nor was it the alternative to Islamic rule. Rather, the intention of participation was to relieve Muslims from oppression and salvage their rights, while at the same time strengthening their social, economic, political, and military positions in order to better confront Westernization and degeneracy. ${ }^{32}$

Alagha, Hizbullah's Identity Construction, 1978-2010 (Amsterdam: Amsterdam University Press, forthcoming).

${ }^{29}$ Harb and Leenders relate what they term the "integrated and holistic network" of Hezbollah to the notion that Hezbollah's institutions manage a diversity of policy sectors: social, educational, medical, urban, economic, cultural and religious. These institutions, besides offering their material and professional help, "also disseminates codes, norms and values that produce what has been designated by the party as the 'Resistance society."' As such, they aptly argue that the resistance "identity" and "culture" are essential products of Hezbollah's institutions. Ibid, p188-190.

${ }^{30}$ Ibid, p. 191.

${ }^{31}$ Naim Qassem, "Kayfa Yankharet Baqi al-Mujtama' fi al-Muqawamah?" (How Does the Rest of Society Integrate with the Resistance?) an-Nahar, June 8, 2007.

${ }^{32}$ Fathi Yakan, Abjadiyat al-Tasawor al-Haraki lil-'Amal al-Islami (The Elementary Facts of the Conceptual Movement of Islamic Activism) (Beirut: Mu'assassat al-Risalah, 1981), pp. 164-166. 
Nevertheless, prior to the first parliamentary elections in twenty years in 1992, the Islamic Association subordinated its decision to participate in the upcoming election to a legal Islamic study. On August 9, 1992, the study, The Islamic Legal Justifications to Enter The Elections Battle, released its findings recommending the Association participate in the parliamentary elections. The study based its findings on the following:

1) to consider parliamentary work as a method of Husbat ${ }^{33}$ (accountability) and a pulpit for "the promotion of virtue and prevention of vice" (al-Amr bi al-Ma'ruf wa Nahi 'an al-Munkkar), especially on the basis of Husbat, which calls for change by way of persuasion and word of mouth, not force, and which Muslims are required to observe in order to achieve the principles of Islamic law, safeguard social life, and protect people from moral deviation;

2) to participate in parliamentary sessions does not mean approving any legislative position contradicting Islamic law. A deputy can object, provide an alternative, criticize or boycott the session. This means that the principle of participation rests with the position and the practice. If the practice is religiously legitimate with the objective of rightly informing legislations and reforming the system, then it is a duty to do so;

3) to participate in parliament sessions is a gateway to $D a$ 'wa, the call to Islam, and an opportunity propagate the faith and its principles through dialogue and conversation;

4) to participate in parliament activities is to provide opportunities to realize peoples' interests, prevent vice, and achieve fair economic development. ${ }^{34}$

Along with these justifications, the study underscored that "its participation would fill the void left by the downfall of the various leftist currents, which until recently monopolized political decisions in the name of Muslims, let alone enhance the nationalist and Jihadi feeling to stand up to the projects of Westernization and to the hegemony and domination practiced by the international system and the oppressive powers in the world." ${ }^{35}$

\section{Islamist Programs, Charters and the Confessional System}

From the time Hezbollah and the Islamic Association decided to participate in Lebanon's confessional system in 1992 under Syrian suzerainty, neither has called for the creation of an Islamic state. Indeed, both movements tempered their political discourse. At the same time, there was a gradual change in the way each of them approached the system and Lebanese Christians.

The Islamic Association's 1992 parliamentary election program asserted that "it is a duty to review all laws that contradict with Islamic law, so long as this would not clash with the beliefs of the rest of the population." ${ }^{36}$ At the same time, it called for the institution of the "principle of

\footnotetext{
${ }^{33}$ Husbah connotes the accountability to obey the religious and moral instructions of Islam, which include financial and social matters.

${ }^{34}$ See the full text of the Islamic Association's study in Fathi Yakan, Adwa' 'ala al-Tajribah al-Niyabiyah al-Islamiyah fi Lubnan: Al-ida' al-Niyabi bayn al-Mabda' wa al-Tatbiq (Lights on the Islamic Parliamentary Experience in Lebanon: The Parliamentary Performance Between Principle and Practice) (Beirut: Mu'assassat al-Risalah, 1996), pp. 179-198.

${ }^{35}$ Ibid.

${ }^{36}$ Al-Jama'a al-Islamiyah (Islamic Association), "al-Barnamej al-Intikhabi li-Murashihi al-Jama'a alIslamiyah," p. 202.
} 
separation of powers so as to prevent interference in the prerogatives among the cabinet, presidency and the parliament." ${ }^{37}$ It also called for the "abolition of the regime of confessional prerogatives [political Maronitism]," which, the program maintained, "requires the recognition of the reality of co-existence and urges the development of an accepted formula for co-existence, heeding the specificities of every sect and their rights to live a free, noble life." ${ }^{38}$

The 2001 political program of the Islamic Association maintained that an "effort should be made to abolish political sectarianism," and that a balanced, just "electoral law should be enacted on the basis of proportional representation on the governorate [province] level..." ${ }^{39}$ But it was the Islamic Association's 2003 Islamic Charter in Lebanon that elaborated and detailed its slightly revised position on the confessional system and the Christians. Interestingly, unlike previous programs, the Charter inserted Koranic verses in every topical section, serving to justify the position of the Islamic Association. Regarding the confessional system, the Charter declared that:

despite the fact that the Islamic regime differs from democracy in some of its aspects, we see political pluralism and the consecration of the right of the citizens to choose their rulers and hold them accountable through free elections, as a civil system endorsed by Islam and suitable with the nature of Lebanese society. But it needs transparency in implementation, and the issuing of firm and just laws that organizes the finest of political activism (Party Laws). It also needs to foster honest general elections, whereby all political forces have equal opportunity (Electoral law). In addition, it needs laws that will organize the powers of the three authorities [presidency, cabinet, and parliament] in a way guaranteeing their separation but complementing their performance ... We cannot but remind about the necessity of dealing with the chronic disease which corrodes and spoils the body of political life-that is to say, political sectarianism. The article in the constitutional document [Document of National Understanding] dealing with the creation of a "Higher Council to Abolish Political Sectarianism" is the natural entry to treat the ramifications of this "undemocratic" configuration. Based on all this, we call for a positive participation in political activism in Lebanon, allowing us to develop our performance to achieve social peace, political stability, and balanced economic development. ${ }^{40}$

Hezbollah, though roughly sharing some of the positions of the Islamic Association, has been more politically adept in its approach to the confessional system and the Christians. Its discourse has been refined and nuanced. As mentioned above, Hezbollah has not called for the establishment of an Islamic state since 1992. Hezbollah's 1992 parliamentary elections program revolved mainly around two objectives: The Liberation of Lebanon from Zionist occupation and the abolishment of political sectarianism. ${ }^{41}$ The program did not vilify political Maronitism or the Maronites, but it conceived that "political sectarianism is one of the biggest fundamental

\footnotetext{
${ }^{37}$ Ibid., p. 202.

${ }^{38}$ Ibid., p. 203.

39 "Al-Jama'a al-Islamiyah Tatruh li-awal Marah Mashru'aha al-Siyasi," (Islamic Association Presents for the First Time its Political Program), as-Safir, April 25, 2001.

40 "Al-Nas al-Kamel li-Mashru' 'al-Mithaq al-Islami fi Lubnan'," (The complete Text of the project of 'The Islamic Charter in Lebanon) Al-Mustaqbal, December 12, 2003.

${ }^{41}$ Qassem, Al-Manhaj, al-Tajribah, al-Mustaqbal, p. 457.
} 
flaws, responsible for the corruption of the current regime in Lebanon and for all the tragedies and political, cultural, social, security, and developmental calamities that have plagued the country." ${ }^{42}$ It called for amending the electoral law so that it becomes more representative of the population, and it proposed adopting two measures: making Lebanon into a single electoral district, and reducing the legal voting age to $18 .{ }^{43}$ In its 1996 parliamentary election program, Hezbollah reiterated its demand for the abolishment of political sectarianism and called for a just and balanced electoral law. In addition to its demands regarding the electoral law in the 1992 program, the party's 1996 program called for proportional representation. ${ }^{44}$ Meanwhile, Hezbollah had begun to engage the Christians.

Hezbollah perceived "dialogue as a means to reach common denominators, which would lead to cooperation on common causes and help resolve disputes, so that conflicts and clashes would not occur, and all groups would continue to uphold their own beliefs and specificities..." ${ }^{45}$ No less significant, Hezbollah included Christians (mainly from the south and Ba'albeck-Hermel regions) on its parliamentary and municipality electoral lists. But, admittedly, this Infitah did not supplant Hezbollah's idea of establishing an Islamic state, which has eventually become a long-term objective. Secretary General Nasrallah explained this goal as follows:

I do not wish [an Islamic State] by force or violence, rather we prefer to wait for the day that we succeed in convincing our countrymen-by means of dialogue and in an open atmosphere-that the only alternative is the founding of an Islamic state. ${ }^{46}$

Subsequently, in its 2000 parliamentary election program, Hezbollah tempered its call for abolishing political sectarianism by emphasizing the establishment, as the Taif Accord stipulated, a National Committee for the Abolishment of Political Sectarianism. This was followed by Nasrallah's 2001 statement which called for the abolition of political sectarianism in the mentality, before abolishing it in the texts ${ }^{47}$; a statement that has become consistent with the Maronite Patriarch's position on political sectarianism whenever the issue of its abolishment has arisen. $^{48}$

${ }^{42}$ Ibid, p. 460.

${ }^{43}$ Ibid., p. 460.

${ }^{44}$ Alagha, The Shifts in Hizbullah's Ideology, pp. 256.

${ }^{45}$ Qassem, Al-Manhaj, al-Tajribah, al-Mustaqbal, p. 360.

${ }^{46}$ See Nasrallah's statement in al-'Ahd, April 10, 1994; as cited initially from Rodger Shanahan, The Shi'a of Lebanon: Clans, Parties and Clerics (London: I.B. Tauris, 2005), p. 104.

${ }^{47}$ See Nasrallah's speech in as-Safir, July 11, 2001; as cited initially from Alagha, Shifts in Hizbulla's Ideology, p. 160.

${ }^{48}$ In response to the President and the Speaker of the House's call for establishing a national committee to abolish political sectarianism in November 2009, Patriarch Sfeir stated that "For some time they have calling for the abolishment of sectarianism, but sectarianism cannot be canceled by a pen. Before abolishing sectarianism from the texts, it should be abolished from the souls." See al-Mustaqbal, November 23, 2009. 
On November 30, 2009, Hezbollah issued its new Political Manifesto underscoring the political vision of the party. ${ }^{49}$ In line with Hezbollah's 1985 Open Letter, the 2009 Manifesto looked at the world through Ayatollah Khomeini's prism dividing the world into the "oppressors" and the "oppressed." But, unlike the Open letter, the Manifesto did not explain its vision in relation to Wilayat al-Faqih. It also moved away from distinguishing its relationship with Lebanon's communal groups. The focal point of the manifesto was the relationship between the Resistance and its legitimate weapons on one side, and the paramountcy of upholding the Resistance on the other, in order to face regional and international dangers.

The Manifesto, unlike the Open letter, does not call for or refer to the creation of an Islamic state in Lebanon; rather it sees Lebanon as the homeland for all Lebanese. It calls for a unitary, unified Lebanon, united in people, land, state and institutions. It opposes any form of partition and federalism. It seeks an independent, sovereign, strong Lebanon, enabled to be present in the regional equations and a chief author of its present and future. The Manifesto stresses that in order to build such a country, Lebanon should have a strong, capable and just state, as well as a political system representing rightfully the aspirations, freedom, dignity, and stability of the population.

As related to The Resistance, the Manifesto affirms the constant threat posed by Israel on Lebanon, and exposes the great danger of Israel's historical ambitions in Lebanon, and the peril it poses to the co-existence of followers of divine revelations that Lebanon uniquely manifests. All this, in addition to the geographic proximity of Lebanon to occupied Palestine, compel Lebanon to bear nationalist and patriotic responsibilities. The Manifesto stresses that the Resistance must consistently reinforce its power and better equip its capabilities to carry out its national responsibilities to liberate Shebaa farms, Kfarshouba Hills, and the Lebanese village of Ghajar, to retrieve detainees, the missing, and the bodies of martyrs, and to participate in the task of protecting and defending the land and the people.

As related to The State and the Political System, the Manifesto asserts that the fundamental problem in the Lebanese political system, which prevents its modernization, development and reform, is political sectarianism. It conditions the application of a true democracy to the abolishment of political sectarianism, as stipulated by the Taif Accord. But it cautions that until the Lebanese, through national dialogue, achieve this sensitive and historic accomplishment, that is abolishing political sectarianism, consensual democracy remains the fundamental basis for ruling Lebanon; because it embodies the spirit of the constitution and the essence of the charter of national co-existence.

Before long, the Islamic Association issued its own Manifesto on June 24, 2010. The Manifesto described the distinctive nature of Lebanon's democratic political system which allows political plurality and a wide range of freedoms, in contrast to other regimes in the region. This is so because of the " nature of the confessional demographic Lebanese structure that makes all constituencies - on their own - minorities incapable of individually appropriating power." But, according to the Manifesto, this partial, positive description does not negate the presence of flaws and imperfections that almost brought down the Lebanese structure from its foundation,

\footnotetext{
${ }^{49}$ See complete text of Hezbollah's Political Manifesto on the website of the party's newspaper al-Intiqad, available at http://www.alintiqad.com/essaydetailsf.php?eid=22807\&fid=43.
} 
and still limit the capacity of the Lebanese regime to develop. True the Taif accord has ended the civil war and introduced fundamental improvements to the political system; yet fundamental articles of the accord have not yet been implemented. This essentially include "creating a national committee to abolish political sectarianism, establishing a modern electoral system that relies on proportional representation; instituting administrative decentralization; and upholding the right of all areas to a balanced development." 50

\section{Conclusion}

Hezbollah's programs, statements and 2009 Manifesto reveal that the party's political maturity and astuteness is being put in the service of its Jihad against Israel while at the same time providing the pretext and praxis to control the state. Hezbollah asserts its Lebanese identity and the unity of Lebanon. But, on the same grounds, it constructs its political program and vision not only regardless of the cultural and political plurality of Lebanon's communities, but also in a way so as to overlay its program and vision over the heads of political parties, all in the name of patriotism.

In fact, Hezbollah's Manifesto is as much a political document as it is an ideological one. The ideological view of Ayatollah Khomeini's bi-polar world of the oppressor versus the oppressed is at the heart of the Manifesto, superfluously manifested in Hezbollah's "permanent" and "irreconcilable" enmity to the United States and Israel, the oppressors of the world. It is from this ideological conviction that Hezbollah outlines its political vision. It makes clear that the permanency of Jihad against Israel is justified and unquestionable, and it seeks to sanction it both constitutionally through consensual democracy whereby a majority cannot impose its political will, and nationalistically through a national defense strategy. More specifically, Hezbollah preordains the national defense strategy by fashioning a strategic duality linking a "popular resistance," i.e. Hezbollah, to a regular army in the interest of confronting Israel. In other words, Hezbollah's Resistance (and weapons) will be at one and the same time part of and separate from the state. Hezbollah's weapons, as referred by the Manifesto, would remain a "fixture" appended to the state but not integrated with the army.

This is bolstered by the ideological conviction of Hezbollah's leadership to confront Israel and provide an alternative culture to that of the West as pronouncedly defined by the United States. This has been manifested, on the one hand, by Hezbollah's attempt to construct a "society of resistance" in place of a resistance for society. Nasrallah, and more so Qassem, have clearly stated that the program and curriculum of the party is about creating a society of resistance, as a panacea to the ills, cruelty and oppression afflicted on Lebanon, and the region, by Israel and its U.S. sponsor.

Taking all this into consideration, one could safely argue that from the time Hezbollah issued its Open Letter in 1985, until 1992, its dual mission had been to wage a Jihad against Israel and Islamize the state through a top-down process. From 1992 onward, as Hezbollah has become a constitutive element of the political system, it has continued its dual mission but with the distinction that it has pursued a gradual bottom-up process to Islamize the state. The vast

\footnotetext{
${ }^{50}$ Ibid., pp. 6-7.
} 
network of its socio-economic institutions, including its enormous social welfare system, only enhances this bottom-up process by widening and sustaining the base of its popular support. ${ }^{51}$ The focal point of this Islamization is to create a society of resistance whereby nationalism and Islamism conflate in the interest of Jihad against Israel. True, Hezbollah's Infitah has helped the Islamist party forge alliances and relationships with groups and parties from all communities. However, the true motive of Infitah and Lebanonization has been to create a political process geared towards supporting the Islamic Resistance and creating the society of resistance. In this respect, Lebanonization and Infitah are not about integrating the Hydra-like Hezbollah into Lebanon's political system but it is about a reverse integration, whereby society and the state would be integrated into Hezbollah's project. In the meantime, Hezbollah, besides trying to fill the state's institutions with its own loyalists, has ingeniously introduced the concept of consensual democracy to protect the Resistance, while at the same time fashioning a national defense strategy to sanction the independence and legitimacy of the Resistance.

Similarly, it is true that the Islamic Association does not subscribe to the doctrine of Wilayat alFaqih and does not see the world through the prism of Ayatollah Khomeini's bi-polar world of "oppressors" and "oppressed," yet the Islamic Association shares with Hezbollah the central tenet that the U.S. and Israel pose the most significant threat to the Ummah. A collation of Hezbollah's and the Islamic Association's Political Manifestos reveal that the two parties support common central issues, though this support does not neatly overlap with the concerns of both parties. Significantly, as long as the Islamic Association shares a "holy alliance" with Hezbollah, premised on Islamic resistance against the "Zionist entity" and the desire to abolish political sectarianism, its political decisions cannot be separated from Hezbollah's nationalist-Islamist vision and political program.

${ }^{51}$ Since the early 1980s, Hezbollah has put a great effort to construct a vast network of various social institutions to help and support the Shia community, which rarely relied on the state for social and economic services and help. Iran has provided Hezbollah with significant financial and organizational help. Some of the institutions include a counterpart of Iran's construction organization, Jihad al-Bina' (Construction Jihad), which was founded in 1984 and later on was licensed by the state; The Islamic Health Committee, established also in 1984, runs hospitals, infirmaries, dental clinics and pharmacies; The Relief Committee of Imam Khomeini, which was founded at the request of Ayatollah Khomeini, has grown into an elaborate social welfare organization, whose services more or less surpass those of the state; and the Martyr Foundation doles money to the families of Hezbollah's martyrs. The organization, aptitude and expanse of Hezbollah's institutions were illustrated in the aftermath of the July 2006 when the party managed to rebuild the heavily damaged southern suburbs in a timely, efficient and fairly aesthetical manner. In fact, in the aftermath of the war, the party, through Jihad al-Bina', launched project $W a^{\prime} d$ (promise) to rebuild the Dahiyah (southern suburbs), bringing together a large group of well known architects, engineers, and contractors. According to eye witness accounts gauging the cost of reconstruction, the bill of the project was in the billions of dollars. For Project Wa'd, and the professionals and technicians associated with it, see "Hezbollah Yatluq Mashru' Wa'd li-I'adat I'mar al-Dahiyah," (Hezbollah Launches Project Wa'd to Rebuild al-Dahiyah) as-Safir, May 25, 2007; For various details on Hezbollah's social organizations, see Shawn Teresa Flanigan and Mounah Abdel-Samad, "Hezbollah's Social Jihad: Nonprofits as Resistance Organizations," Middle East Policy, Vol. 16, No. 2 (Summer 2009); Hala Jaber, Hezbollah: Born with a Vengeance (New York: Columbia University Press, 1997), pp. 145-168; A. Nizar Hamzeh, "Lebanon's Hizbullah: From Islamic Revolution to Parliamentary Accommodation," Third World Quarterly, Vol. 14, No. 2 (1993); and Robert G. Rabil, "Hezbollah: Lebanon's Power Broker," The Journal of International Security Affairs, No. 15 (Fall 2008). 


\section{Bibliography}

Alagha, Joseph. Hizbullah's Documents: From the 1985 Open Letter to the 2009 Manifesto (Amsterdam: Pallas Publications, 2011).

Alagha, Joseph. Hizbullah's Identity Construction, 1978-2010 (Amsterdam: Amsterdam University Press, 2011).

Al-Jama'a al-Islamiyah Tatruh li-awal Marah Mashru'aha al-Siyasi," (Islamic Association Presents for the First Time its Political Program), as-Safir, April 25, 2001.

Dick, Marlin. "Hizballah's Domestic Growing Pains," Middle East Report Online, September 13, 2010; available at http://www.merip.org/mero/mero091310.html.

Fadlallah, Hassan. Al-Khiyar al-Akhar: Hezbollah: Al-Sirah al-Zatiyyah wa al-Mawqaf (The Other Choice: Hezbollah's Autobiography and Stance) (Beirut: Dar al-Hadi, 1994).

Hamzeh, Nizar A. "Lebanon's Hizbullah: From Islamic Revolution to Parliamentary Accommodation," Third World Quarterly, Vol. 14, No. 2 (1993).

Harik, Judith Palmer. Hezbollah: The Changing Face of Terrorism (London: I.B. Tauris, 2004).

Islamic Association. "Al-Nas al-Kamel li-Mashru' 'al-Mithaq al-Islami fi Lubnan'," (The complete Text of the project of 'The Islamic Charter in Lebanon) Al-Mustaqbal, December 12, 2003.

Jaber, Hala. Hezbollah: Born with a Vengeance (New York: Columbia University Press, 1997).

Maila, Joseph. The Document of National Understanding: A Commentary (Oxford: Centre for Lebanese Studies, 1992).

Mona Harb and Leenders, Reinoud. "Know Thy Enemy: Hizbullah, 'Terrorism' and the Politics of Perception," Third World Quarterly, Vol. 26, No. 1 (2005).

Nasrallah, Fida. Prospects for Lebanon: The Question of South Lebanon (Oxford: Centre for Lebanese Studies, 1992).

Noe, Nicolas. ed., Voice of Hezbollah: The Statements of Sayyed Hassan Nasrallah (London: Verso, 2007).

Norton, Augustus Richard. "Lebanon After Ta'if: Is the Civil War Over?" Middle East Journal, Vol. 45, No. 3 (Summer 1991). 
Norton, Richard Augustus. "Hizbullah: From Radicalization to Pragmatism?" Middle East Policy, Vol. 4, No. 4 (January 1998).

Pakradouni, Karim. La'nat Watan: Min Harb Lubnan Ila Harb al-Khalij (Curse of a Fatherland: From the Lebanese War to the Gulf War) (Beirut: Trans-Orient Press, 1992).

Pakradouni, Karim. Sadmah wa Sumud: 'Ahd Emile Lahoud (1998-2007), (Shock and Steadfastness: The Era of Emile Lahoud (1998-2007)) (Beirut: All Prints Distributors \& Publishers, 2nd edition, 2009).

Qassem, Naim. "Kayfa Yankharet Baqi al-Mujtama' fi al-Muqawamah?" (How Does the Rest of Society Integrate with the Resistance?) an-Nahar, June 8, 2007.

Qassem, Naim. Hizbullah: Al-Manhaj, al-Tajribah, al-Mustaqbal (Hizbullah: The Curriculum [program], the Experience, The Future) (Beirut: Dar al-Hadi, 6th edition, 2009).

Rabil, Robert G. "Hezbollah: Lebanon's Power Broker," The Journal of International Security Affairs, No. 15 (Fall 2008).

Rabil, Robert G. Embattled Neighbors: Syria, Israel and Lebanon (Boulder, CO: Lynne Rienner Publishers, 2003).

Rabil, Robert G. Syria, United States and the War on Terror in the Middle East (Wesport, CT: Praeger Security International, 2006).

Rabil, Robert G. Religion, National Identity and Confessional Politics in Lebanon: The Challenge of Islamism (New York: Palgrave Macmillan, 2011).

Ranstorp, Magnus. "The Strategy and Tactics of Hizballa's Current Lebanonization Process," Mediterranean Politics, Vol. 3, No. 1 (1998).

Saad-Ghorayeb, Amal. Hizbu'llah: Politics and Religion (London: Pluto press, 2002).

Shanahan, Roger. The Shi'a of Lebanon: Clans, Parties and Clerics (London: I.B. Tauris, 2005).

Shawn Teresa Flanigan and Abdel-Samad, Mounah. "Hezbollah's Social Jihad: Nonprofits as Resistance Organizations," Middle East Policy, Vol. 16, No. 2 (Summer 2009).

Shaykh Muhammad Hussayn Fadlallah and Soueid, Mahmoud. "Islamic Unity and Political Change: Interview with Shaykh Muhammad Hussayn Fadlallah," Journal of Palestine Studies, Vol. 25, No. 1 (Autumn, 1995).

Yakan, Fathi. Abjadiyat al-Tasawor al-Haraki lil-'Amal al-Islami (The Elementary Facts of the Conceptual Movement of Islamic Activism) (Beirut: Mu'assassat al-Risalah, 1981). 
Yakan, Fathi. Adwa' 'ala al-Tajribah al-Niyabiyah al-Islamiyah fi Lubnan: Al-ida' al-Niyabi bayn al-Mabda' wa al-Tatbiq (Lights on the Islamic Parliamentary Experience in Lebanon: The Parliamentary Performance Between Principle and Practice) (Beirut: Mu'assassat al-Risalah, 1996).

* Dr. Robert G. Rabil is an associate professor of political science at Florida Atlantic University. He is the author of Religion, National Identity and Confessional Politics in Lebanon: The Challenge of Islamism (Palgrave Macmillan, 2011); Syria, United States and the War on Terror in the Middle East (Praeger, 2006); and Embattled Neighbors: Syria, Israel and Lebanon (Lynne Rienner Publishers, 2003). 